\title{
Using Cowpea to Manage Soil Phosphorus Accumulation from Poultry Litter Applications in a Cool-season Vegetable Rotation
}

\author{
Clydette M. Alsup ${ }^{1}$ and Brian A. Kahn ${ }^{2}$ \\ Department of Horticulture and Landscape Architecture, Oklahoma State \\ University, Stillwater, OK 74078-6027
}

Mark E. Payton ${ }^{3}$

Department of Statistics, Oklahoma State University, Stillwater, OK 74078-1056

\begin{abstract}
Additional index words. Brassica oleracea, Brassica rapa, Spinacia oleracea, Vigna unguiculata, cover crop, sustainable agriculture
\end{abstract}

\begin{abstract}
Cowpea [Vigna unguiculata (L.) Walp.] cover crops were grown in a rotation with broccoli (Brassica oleracea L. var. italica Plenck.), spinach (Spinacia oleracea L.), and turnip greens [Brassica rapa L. var. (DC.) Metzg. utilis] to evaluate the legume's ability to remove excess $P$ from soils when poultry litter was used as a fertilizer. Fertilizer treatments were: 1) litter to meet each crop's recommended preplant $N$ requirements $(1 \times) ; 2)$ litter at twice the recommended rate $(2 \times)$; and 3 ) urea at the $1 \times$ rate as the control. Following the vegetable crops, cowpeas were planted on half of each replication, while the other half was fallowed. The cowpeas were harvested at the green-shell seed stage and then underwent a simulated haying operation to remove remaining shoot material from the field. Soil samples were taken at $0-15 \mathrm{~cm}$ and $15-30 \mathrm{~cm}$ depths at the onset of the study and after each crop to monitor plant nutrient concentrations. The cowpeas lowered soil test $N$ concentrations at both soil sampling depths, but had no consistent effect on soil test $P$ concentrations. Soil test $P$ at the $0-15 \mathrm{~cm}$ depth was not increased by litter at the $1 \times$ rate but was increased by litter at the $2 \times$ rate relative to the urea control, regardless of cropping system. Poultry litter was effective as a fertilizer for all three vegetable crops, but the $1 \times$ rate appeared inadequate for maximum production of broccoli and turnip greens.
\end{abstract}

The poultry industry has grown in the south central United States, with U.S. production in 1997 reaching an estimated 7.76 billion broiler chickens (Gallus gallus domesticus L.) (National Agricultural Statistics Service, 1998). The increase in production has been accompanied by a greater output of poultry litter, with $\approx 40$ million $\mathrm{Mg}$ of dry manure produced each year. Many states and regions have begun regulating animal waste disposal methods. Government restrictions, combined with an

Received for publication 23 May 2001. Accepted for publication 8 Oct. 2001. Approved for publication by the Director, Oklahoma Agricultural Experiment Station. This research was supported in part under project H-2026 and in part under project LS95-69 from the Southern Region Sustainable Agriculture Research and Education (SARE) program. The information given in this publication is for educational purposes only. Mention of a trademark, proprietary product, or vendor does not constitute a guarantee or warranty of the product, nor does it imply approval or disapproval to the exclusion of other products or vendors that may also be suitable.

${ }^{1}$ Former Graduate Research Assistant. Present address: Dept. of Agriculture, Southwest Missouri State Univ., 901 S. National Avenue, Springfield, MO 65804 .

${ }^{2}$ Professor. To whom reprint requests should be addressed.

${ }^{3}$ Associate Professor and Experiment Station Statistician. increasing emphasis on sustainable agricultural practices, have led to more frequent use of poultry litter as a fertilizer for vegetable and other agricultural crops. Sims and Wolf (1994) have reviewed poultry waste management issues.

Poultry litter contains most mineral elements essential for plant growth and adds organic matter to the soil, making it a potential alternative fertilizer source for horticultural crops (Edwards and Daniel, 1992; Sims and Wolf, 1994). Research in greenhouses and in the field has shown mixed results on the effectiveness of poultry manure or litter as a fertilizer for fruits and vegetables. Cool-season crops of the Brassicaceae such as broccoli, cabbage (Brassica oleracea L. var. capitata L.), cauliflower (Brassica oleracea L. var. botrytis L.), collards (Brassica oleracea L. var. acephala DC.), and turnips have been successfully grown with poultry litter or manure (Brown et al., 1994; Earhart, 1995; Guertal et al., 1997; Lu and Edwards, 1994; Maynard, 1994; Ware and Johnson, 1968).

Field applications of poultry litter have traditionally been based on the $\mathrm{N}$ needs of the crops being produced. Poultry litter is low in $\mathrm{N}$, so large quantities may be needed to supply enough $\mathrm{N}$ to meet crop demands. Application of a large amount of litter can cause a buildup of soil P (Edwards and Daniel, 1992; Kingery et al., 1994; Sharpley et al., 1993), because plants tend to take up less $\mathrm{P}$ than is provided in litter. The ratio of $\mathrm{N}$ : $\mathrm{P}$ uptake for crops grown in the Southern Plains region of the United States is $8: 1$, while the average $\mathrm{N}: \mathrm{P}$ ratio in litter is 3:1 (Edwards and Daniel, 1992). Excessive $\mathrm{P}$ near the soil surface is subject to rainfall runoff (Edwards and Daniel, 1993; Nichols et al., 1994), and may be carried to surface bodies of water where it may accelerate eutrophication. Concentrations of $\mathrm{P}$ must be managed if poultry litter is to be used as a long-term fertilizer in agricultural production.

Eastern Oklahoma has a substantial poultry industry and considerable commercial vegetable production. Much of this vegetable production is on river bottom land that has been cropped for many years; the Vegetable Research Station in Bixby, Okla. is representative of such land. These sandy soils tend to be adequate to high in $\mathrm{P}$, but low in $\mathrm{N}$ and would benefit from organic matter addition. Poultry litter could be a useful fertilizer in this situation if the $P$ accumulation was controlled. Poultry litter cannot readily be applied at the recommended $\mathrm{P}$ fertilization rate on such soils because little or no added $\mathrm{P}$ is likely to be needed (Sharpley et al., 1993). Therefore, our research has taken the approach of using litter to meet preplant $\mathrm{N}$ needs while seeking alternatives to control the buildup of $\mathrm{P}$ in the soil.

Legumes tend to take up P at relatively high rates, and so may deplete soil $\mathrm{P}$ (Griffith, 1974). Daniel (1934) analyzed the plant nutrient content of 23 grasses and 10 legumes and found that legumes contain an average of 1.75 times as much $\mathrm{P}$ as grasses. The foliar $\mathrm{P}$ concentration of cowpeas (average of $0.165 \%$ ) compared favorably with that of other warmseason legumes tested by Daniel (1934). Bray$P$ values in the $0-15 \mathrm{~cm}$ soil sampling depth were lower under legume cover crops than grass covers (Wilson et al., 1982). Winter legumes lowered soil $\mathrm{pH}$ and extractable $\mathrm{P}$ in the $0-7.5 \mathrm{~cm}$ soil sampling depth and redistributed K to the soil surface (Hargrove, 1986). Cover crops absorb nutrients while actively growing, and if significant biomass accumulates, the cover crops could affect the distribution and forms of plant nutrients in soils (Lal et al., 1991).

Earhart (1995) proposed that vegetable crops be rotated with legume cover crops to reduce soil $\mathrm{P}$ accumulation from poultry litter applications. This study was initiated to determine the ability of cowpea cover crops to reduce soil $\mathrm{P}$ concentrations in a cool-season vegetable rotation where poultry litter was used for preplant fertilization of the vegetable crops.

\section{Materials and Methods}

A 3-year field experiment was conducted at the Vegetable Research Station in Bixby, Okla., on a Severn very fine sandy loam [coarsesilty, mixed (calcareous), thermic Typic Udifluvent]. A split-plot arrangement was used in a randomized complete-block design with four replications. The main plot treatment was cover crop: after each vegetable crop was 
harvested, cowpeas were planted on half of each replication, with the other half left fallow. The sub-plot treatments consisted of poultry litter at a rate sufficient to meet each crop's recommended preplant $\mathrm{N}$ requirements $(1 \times)$; litter at twice the recommended rate $(2 \times)$; and urea $(46 \% \mathrm{~N})$ at the $1 \times$ rate as the control. Thus, each replication contained six plots, each measuring $5.4 \mathrm{~m} \times 8.0 \mathrm{~m}$. Each replication was separated by a 2-m alley, and there was a 3-m alley in the center of the field. The same field was used each year, and plot integrity was maintained for the duration of the study.

Litter was obtained from three poultry farms in the northeastern Oklahoma area. The litter was obtained from direct clean-outs of empty poultry houses; thus, it was slightly aged but not composted. Before application, the litter was analyzed for $\mathrm{pH}$, electrical conductivity, percent water, and total $\mathrm{N}, \mathrm{P}, \mathrm{K}$, and $\mathrm{Ca}$ by the Univ. of Arkansas' Agricultural Services Laboratory in Fayetteville (Table 1). Total amount of litter applied and the rates of $\mathrm{N}, \mathrm{P}$, and $\mathrm{K}$ applied with fertilizer treatments were recorded (Table 2). Fertilizer materials were broadcast by hand and incorporated to a depth of $5-8 \mathrm{~cm}$ with a tractor-powered rototiller.

Before any crops were planted, soil samples were collected from each plot at two depths: $0-15 \mathrm{~cm}$ and $15-30 \mathrm{~cm}$, and analyzed for $\mathrm{pH}$, nitrate- $\mathrm{N}, \mathrm{P}, \mathrm{K}, \mathrm{Ca}, \mathrm{Mg}, \mathrm{Fe}, \mathrm{B}$, and $\mathrm{Zn}$. Five soil cores were removed from each plot and mixed to form a composite sample. Baseline samples were taken on 25 July 1995, before the first vegetable crop (broccoli) was planted. Soil samples were also collected before and after each legume cover crop and vegetable crop. Sampling periods will be abbreviated as follows: $\mathrm{T} 1=25$ July 1995; T2 = 29 May 1996; T3 = 3 Sept. 1996; T4 = 14 May 1997; T5 = 19 Sept. 1997; and T6 = 13 May 1998. Timing of sample collections was as consistent as possible, but varied depending on the weather, field conditions, and crop phenology. The elements $\mathrm{Ca}, \mathrm{Mg}, \mathrm{Fe}, \mathrm{B}$, and $\mathrm{Zn}$ were evaluated only at T1, T3, and T5, as they were not the main focus of the study.

Soil samples were analyzed by the Oklahoma State Univ. Soil, Water and Forage Analytical Laboratory in Stillwater, using calcium sulfate extraction of nitrate-N; the Mehlich III extraction for $\mathrm{P}, \mathrm{K}, \mathrm{Ca}$, and $\mathrm{Mg}$; diethylenetriaminepentaacetic acid (DTPA) extraction of $\mathrm{Fe}$ and $\mathrm{Zn}$; and hot water extraction of B. Phosphate (phospho-molybdate blue) and nitrate (cadmium reduction) were analyzed colorimetrically using flow injection instrumentation. Solutions containing the other elements were analyzed using inductively coupled plasma emission spectroscopy (Zhang et al., 1998)

The fertilizer $1 \times$ treatment rates were determined by averaging the residual soil test $\mathrm{N}$ values at the $0-15 \mathrm{~cm}$ sampling depth in the eight control plots for the sampling times before vegetable crop establishment (T1, T3, and T5). Supplemental fertilizer (urea or poultry litter) was applied at rates based on total percent $\mathrm{N}$ that, when combined with the residual $\mathrm{N}$ levels, brought preplant soil test $\mathrm{N}$ to

Table 1. Elemental composition of three poultry litter lots applied in a 3-year experiment, Bixby, Okla. ${ }^{2}$

\begin{tabular}{lccccccc}
\hline \hline Application time & $\mathrm{pH}$ & $\begin{array}{c}\mathrm{EC}^{\mathrm{y}} \\
\left(\mathrm{dS} \cdot \mathrm{m}^{-1}\right)\end{array}$ & $\begin{array}{c}\mathrm{H}_{2} \mathrm{O} \\
(\%)\end{array}$ & $\begin{array}{c}\mathrm{N} \\
(\%)\end{array}$ & $\begin{array}{c}\mathrm{P} \\
(\%)\end{array}$ & $\begin{array}{c}\mathrm{K} \\
(\%)\end{array}$ & $\begin{array}{c}\mathrm{Ca} \\
(\%)\end{array}$ \\
\hline 17 Aug. 1995 & 7.3 & 11.1 & 20.2 & 3.74 & 1.23 & 2.06 & 2.48 \\
24 Sept. 1996 & 7.1 & 12.3 & 18.4 & 3.62 & 1.31 & 2.71 & 1.89 \\
29 Sept. 1997 & 6.9 & 12.0 & 27.5 & 2.66 & 1.34 & 1.84 & 2.55 \\
\hline
\end{tabular}

${ }^{2}$ Analyses performed by Univ. of Arkansas, Fayetteville. Values are reported on an "as-is" basis, since litter was applied "as is."

${ }^{\mathrm{y}} \mathrm{EC}=$ electrical conductivity.

the recommended levels for each crop. These calculated rates for the poultry litter were doubled to create the litter $2 \times$ rates.

Three cool-season vegetable crops were grown: 'Everest' broccoli, 'Ozarka II' spinach, and 'Alltop' turnip greens. Commercial insect, weed and disease control methods were followed according to Oklahoma Cooperative Extension Service recommendations. Sprinkler irrigation was used as needed to prevent drought stress. Fallow areas were tilled shallowly $(5-8 \mathrm{~cm})$ as needed to control weeds. After harvests of cover crops or vegetable crops, plots were disked and worked with a field cultivator to a depth of $12-15 \mathrm{~cm}$.

Broccoli. The broccoli was direct seeded on 17 Aug. 1995 at an in-row spacing of $10 \mathrm{~cm}$ between seeds, in four rows $0.9 \mathrm{~m}$ apart per plot. Control plots contained an average of 33 $\mathrm{kg} \cdot \mathrm{ha}^{-1}$ residual soil N. Preplant urea and litter $1 \times$ rates added $67 \mathrm{~kg} \cdot \mathrm{ha}^{-1} \mathrm{~N}$, while the litter $2 \times$ rate added $134 \mathrm{~kg} \cdot \mathrm{ha}^{-1} \mathrm{~N}$. Before planting, incorporation was done for the fertilizer materials, plus 2,6-dinitro- $N, N$-dipropyl-4(trifluoromethyl)benzenamine (trifluralin) at $560 \mathrm{~g} \cdot \mathrm{ha}^{-1}$ for weed control, and $O, O$-diethyl $O$-(2-isopropyl-6-methyl-4-pyrimidinyl) phosphorothioate (diazinon) at $4.5 \mathrm{~kg} \cdot \mathrm{ha}^{-1}$ for soil insect control.

Seedlings were thinned on 7 Sept. to one plant every $20 \mathrm{~cm}$. All broccoli plots received topdressings of $50 \mathrm{~kg} \cdot \mathrm{ha}^{-1} \mathrm{~N}$ from urea on 22 Sept. and 6 Oct. Representative samples of petioles were taken from four plants per plot on 13 Oct. to determine foliar $\mathrm{N}$ concentration. Marketable broccoli heads were hand-harvested on 23, 27, and 30 Oct. and 2 Nov. The few nonmarketable heads were not harvested. About 30 plants were harvested from the middle two rows of each plot, for a total sampling area of $5.4 \mathrm{~m}^{2}$ per plot. Stalks were trimmed to 20.5 $\mathrm{cm}$ from the top of the dome before the heads were weighed.

Spinach. The spinach was seeded on 24 Sept. 1996 and replanted on 8 Oct. due to a stand failure (over $8 \mathrm{~cm}$ of rain caused severe soil crusting). Seeds were sown $2.5 \mathrm{~cm}$ apart in rows $0.6 \mathrm{~m}$ apart. Each plot contained three 4-row "beds" (not raised). Control plots contained an average of $50 \mathrm{~kg} \cdot \mathrm{ha}^{-1}$ residual soil N. Preplant urea and litter $1 \times$ rates added $35 \mathrm{~kg} \cdot \mathrm{ha}^{-1} \mathrm{~N}$, while the litter $2 \times$ rate added $70 \mathrm{~kg} \cdot \mathrm{ha}^{-1} \mathrm{~N}$. Before the first planting, incorporation was done for the fertilizer materials, plus 2-chloro- $N$-(2-ethyl-6methylphenyl)- $N$-(2-methoxy-1-methylethyl) acetamide (metolachlor) at $1.1 \mathrm{~kg} \cdot \mathrm{ha}^{-1}$ for weed control. Disking of the failed stand necessitated use of another herbicide, so on 7 Oct.,
$S$-ethyl $N$-ethylthio-cyclohexane-carbamate (cycloate) at $3.4 \mathrm{~kg} \cdot \mathrm{ha}^{-1}$ was applied and incorporated.

The replanted spinach was too small for a fall harvest, and was overwintered. A topdressing of ammonium nitrate to supply $36.7 \mathrm{~kg} \cdot \mathrm{ha}^{-1}$ of $\mathrm{N}$ plus ammonium sulfate to supply $18.3 \mathrm{~kg} \cdot \mathrm{ha}^{-1}$ of $\mathrm{N}$ was applied on 10 Feb. 1997. The spinach was harvested on 15 Apr. 1997. Plants were cut by hand at soil level from a 3-m section of the center bed of each plot for a total harvested area of $5.4 \mathrm{~m}^{2}$ per plot. Plants were counted and weighed, and representative subsamples were taken for dry weight determination and foliar analysis.

Turnip greens. The turnip greens were seeded on 30 Sept. 1997 at an in-row spacing of $\approx 50$ seeds per $\mathrm{m}$, in rows $0.6 \mathrm{~m}$ apart. Each plot contained three 4-row "beds" (not raised). Control plots contained an average of $37 \mathrm{~kg} \cdot \mathrm{ha}^{-1}$ residual soil N. Preplant urea and litter $1 \times$ rates added $48 \mathrm{~kg} \cdot \mathrm{ha}^{-1} \mathrm{~N}$, while the litter $2 \times$ rate added $96 \mathrm{~kg} \cdot \mathrm{ha}^{-1} \mathrm{~N}$. Before plant-

Table 2. Amounts of poultry litter and N, P, and $\mathrm{K}$ applied in a 3-year experiment, Bixby, Okla. ${ }^{2}$

\begin{tabular}{|c|c|c|c|}
\hline \multirow[b]{2}{*}{ Variable } & \multicolumn{3}{|c|}{ Fertilizer treatment } \\
\hline & Urea & Litter $1 \times$ & Litter 2$\rangle$ \\
\hline \multicolumn{4}{|c|}{ Broccoli, 1995} \\
\hline Litter $\left(\mathrm{kg} \cdot \mathrm{ha}^{-1}\right)$ & 0 & 1798 & 3596 \\
\hline $\mathrm{N}\left(\mathrm{kg} \cdot \mathrm{ha}^{-1}\right)$ & 167 & 167 & 234 \\
\hline $\mathrm{P}\left(\mathrm{kg} \cdot \mathrm{ha}^{-1}\right)$ & 0 & 22 & 44 \\
\hline $\mathrm{K}\left(\mathrm{kg} \cdot \mathrm{ha}^{-1}\right)$ & 0 & 37 & 74 \\
\hline \multicolumn{4}{|c|}{ Spinach, 1996-97 } \\
\hline Litter $\left(\mathrm{kg} \cdot \mathrm{ha}^{-1}\right)$ & 0 & 960 & 1919 \\
\hline $\mathrm{N}\left(\mathrm{kg} \cdot \mathrm{ha}^{-1}\right)$ & 90 & 90 & 125 \\
\hline $\mathrm{P}\left(\mathrm{kg} \cdot \mathrm{ha}^{-1}\right)$ & 0 & 13 & 26 \\
\hline $\mathrm{K}\left(\mathrm{kg} \cdot \mathrm{ha}^{-1}\right)$ & 0 & 26 & 52 \\
\hline \multicolumn{4}{|c|}{ Turnip greens, 1997} \\
\hline Litter $\left(\mathrm{kg} \cdot \mathrm{ha}^{-1}\right)$ & 0 & 1813 & 3625 \\
\hline $\mathrm{N}\left(\mathrm{kg} \cdot \mathrm{ha}^{-1}\right)$ & 103 & 103 & 151 \\
\hline $\mathrm{P}\left(\mathrm{kg} \cdot \mathrm{ha}^{-1}\right)$ & 0 & 24 & 48 \\
\hline $\mathrm{K}\left(\mathrm{kg} \cdot \mathrm{ha}^{-1}\right)$ & 0 & 33 & 66 \\
\hline \multicolumn{4}{|c|}{ Total } \\
\hline Litter $\left(\mathrm{kg} \cdot \mathrm{ha}^{-1}\right)$ & 0 & 4571 & 9140 \\
\hline $\mathrm{N}\left(\mathrm{kg} \cdot \mathrm{ha}^{-1}\right)$ & 360 & 360 & 510 \\
\hline $\mathrm{P}\left(\mathrm{kg} \cdot \mathrm{ha}^{-1}\right)$ & 0 & 59 & 118 \\
\hline $\mathrm{K}\left(\mathrm{kg} \cdot \mathrm{ha}^{-1}\right)$ & 0 & 96 & 192 \\
\hline
\end{tabular}

${ }^{\text {ZLitter values reported on an "as is" basis. Nitrogen }}$ values include topdressings of urea (broccoli, turnip greens) or $\mathrm{NH}_{4} \mathrm{NO}_{3}$ plus $\left(\mathrm{NH}_{4}\right)_{2} \mathrm{SO}_{4}$ (spinach) made to vegetable crops as follows: the broccoli received $50 \mathrm{~kg} / \mathrm{ha}$ of $\mathrm{N}$ on 22 Sept. 1995 and on 6 Oct. 1995; the spinach received $55 \mathrm{~kg} \cdot \mathrm{ha}^{-1}$ of $\mathrm{N}$ on $10 \mathrm{Feb}$. 1997; and the turnip greens received $55 \mathrm{~kg} \cdot \mathrm{ha}^{-1}$ of $\mathrm{N}$ on 23 Oct. 1997. Plots fertilized with urea did not receive supplemental $\mathrm{P}$ or $\mathrm{K}$. Plots fertilized with poultry litter received supplemental $\mathrm{P}$ and $\mathrm{K}$ only as provided by the litter. Presence or absence of a cover crop did not affect fertilization practices 
ing, incorporation was done for the fertilizer materials, plus trifluralin at $280 \mathrm{~g} \cdot \mathrm{ha}^{-1}$ for weed control. A topdressing of urea to supply $55 \mathrm{~kg} \cdot \mathrm{ha}^{-1}$ of $\mathrm{N}$ was applied on 23 Oct. The crop was harvested on 7 Nov. 1997 following the same procedures as with the spinach crop, except that plants were cut by hand $\approx 2 \mathrm{~cm}$ above the soil level. Data were collected and subsamples taken.

Cowpea cover crops. 'Mississippi Pinkeye' cowpeas were grown on half of each replication, with the other plots fallowed, in the summers of 1996 and 1997. The seeds were treated with a slurry of $19 \mathrm{~g}$ of cowpeatype Rhizobium inoculant in $36 \mathrm{~mL}$ water per $4.6 \mathrm{~kg}$ of seed. No fertilizers were applied to the cowpea crops. Each plot contained six rows, $0.9 \mathrm{~m}$ apart, of cowpeas. Seeds were planted at $5 \mathrm{~cm}$ apart within rows and seedlings later were thinned to $10 \mathrm{~cm}$ apart. In 1996, the crop was planted on 31 May and metolachlor herbicide was applied at $1.1 \mathrm{~kg} \cdot \mathrm{ha}^{-1}$. The cowpeas were thinned on 3 July and harvested on 2 Aug. The 1997 crop was planted on 29 May, but due to a poor stand was replanted on 20 June. Two herbicides were applied on 1 Junemetolachlor at $1.1 \mathrm{~kg} \cdot \mathrm{ha}^{-1}$ and $N$-(phosphonomethyl)glycine (glyphosate) at $3.4 \mathrm{~kg} \cdot \mathrm{ha}^{-1}$. Harvest was on 28 Aug.

In both years, one data row was harvested in each plot by hand-cutting plants near the ground level. Plants were depodded, marketable pods were shelled, and green-shell seeds were weighed. Depodded plants were placed in burlap sacks, dried and weighed. Representative foliar samples were collected for elemental analysis. The remaining crop was harvested within $24 \mathrm{~h}$ using a flail-vacuum mower and removed from the field in a simulated haying operation.

Tissue analyses. Foliar samples, collected as previously described, were dried at $48{ }^{\circ} \mathrm{C}$ for $\geq 7 \mathrm{~d}$ and reweighed, then ground in a Wiley mill to pass through a no. 40 U.S. standard testing sieve $(0.42 \mathrm{~mm})$. The samples were analyzed by the Samuel Roberts Noble Foundation, Ardmore, Okla., or Ward Laboratory, Kearney, Nebr. Except for broccoli, for which only $\mathrm{N}$ concentration was determined, all crops were analyzed for concentrations of $\mathrm{N}$ (crude protein), $\mathrm{P}, \mathrm{K}, \mathrm{Ca}, \mathrm{Mg}, \mathrm{Mn}, \mathrm{Fe}$, and $\mathrm{Zn}$.

Statistical analyses. Data were evaluated with analysis of variance procedures and the MIXED procedure of the Statistical Analysis System (SAS) (SAS Institute, 1999). Cowpea data were analyzed by year for effects of fertilizer treatment. Vegetable crop data were analyzed by year for main effects of cover crop, main effects of fertilizer treatment, and interactions. Soils data were analyzed across the six sampling times, so these analyses included main effects of cover crop, fertilizer treatment, and time, as well as interactions. If the main effect of fertilizer treatment was significant $(P \leq 0.05)$, means were separated using the least significant difference (LSD) at $P \leq 0.05$. For the soils data, trend analysis was used to partition main effects of time into linear and quadratic components. Significant interactions were partitioned with SAS using the SLICE option in a LSMEANS statement, with means separated using a DIFF option and a significance level of 0.05 .

\section{Results and Discussion}

Broccoli. Litter at the $1 \times$ rate was not adequate for maximum production of marketable broccoli. Plants grown with the litter $1 \times$ rate had less petiole $\mathrm{N}$ and smaller marketable heads than plants grown with the other two fertilizer treatments (Table 3). Total marketable head weight was lower with the litter $1 \times$ rate than with urea, while total marketable head weight of plants grown with the litter $2 x$ rate did not differ from either of the other two fertilizer treatments. Broiler litter $\mathrm{N}$ efficiencies range from $10 \%$ to $49 \%$ of inorganic fertilizer N (Nicholson et al., 1999), which can explain our broccoli yield results. However, Earhart (1995) did not report yield reductions in broccoli fertilized by litter at a rate matching an inorganic fertilizer control. Other studies on litter as a fertilizer for broccoli (Brown et al., 1994; Maynard, 1994) used extremely high application rates compared to our $1 \times$ and $2 \times$ rates.

The broccoli was the only vegetable crop in our study not preceded by a cover crop treatment. A test of cover crop effects to determine if there were random effects of position in the field was statistically nonsignificant.

Spinach. The spinach harvest was $10 \mathrm{~d}$ behind schedule due to persistent rains, so the plants were overmature and starting to bolt. Spinach plants receiving the litter $2 \times$ rate were more succulent than plants in the litter $1 \times$ plots, with higher $\mathrm{N}$ and less dry matter (Tables 4 and 5). Neither litter treatment differed from urea in dry matter and $\mathrm{N}$ concentration.

Spinach stands were reduced in plots receiving the litter $2 \times$ rate (Table 4 ). However, individual plants compensated for the decreased population by growing larger. As a result, total yields on a fresh weight per hectare basis were similar for all treatments. Stand differences could have been caused by seedling injury from the litter $2 \times$ treatment. Adverse effects of high rates of litter application have been reported on other crops (Edwards and Daniel, 1992), but the litter rates used were much higher than those used in our study.

The main effect of cover crop treatment was not significant for any measured variable involving spinach plants. However, a cover crop by fertilizer treatment interaction was evident for shoot Ca concentrations (Table 5). Fertilizer treatments did not affect shoot $\mathrm{Ca}$ concentrations for spinach plants that followed cowpeas. For spinach following fallow, plants from litter $1 \times$ and litter $2 \times$ plots were similar in shoot $\mathrm{Ca}$ concentrations $(2.5 \%$ and $2.6 \%$, respectively), but plants grown with litter $2 \times$ were higher in $\mathrm{Ca}$ than plants grown with urea $(2.1 \%)$.

Turnip greens. Turnip greens grown in the litter $1 \times$ plots had lower fresh weights per hectare and a higher percentage of dry weight than plants grown with the other two fertilizer treatments (Table 4). Stand and fresh weight per plant were not affected by fertilizer treatments.

A cover crop $\times$ fertilizer treatment interac-

Table 3. Effects of fertilizer treatments on 'Everest' broccoli, Bixby, Okla., 1995. ${ }^{2}$

\begin{tabular}{|c|c|c|c|c|}
\hline \multirow{2}{*}{$\begin{array}{l}\text { Fertilizer } \\
\text { treatment }\end{array}$} & \multicolumn{2}{|c|}{ Marketable heads } & \multirow{2}{*}{$\begin{array}{l}\text { Days to first } \\
\text { harvest (no.) }\end{array}$} & \multirow{2}{*}{$\begin{array}{c}\text { Petiole N } \\
(\%)\end{array}$} \\
\hline & $\left(\mathrm{Mg} \cdot \mathrm{ha}^{-1}\right)$ & $(\mathrm{g} / \mathrm{head})$ & & \\
\hline Urea & $12.5 \mathrm{a}$ & $257 \mathrm{a}$ & 68 & $4.6 \mathrm{a}$ \\
\hline Litter $1 \times$ & $10.4 \mathrm{~b}$ & $223 \mathrm{~b}$ & 70 & $3.4 \mathrm{~b}$ \\
\hline Litter $2 x$ & $11.2 \mathrm{ab}$ & 248 a & 70 & $4.1 \mathrm{a}$ \\
\hline Significance & $*$ & $*$ & NS & $* *$ \\
\hline
\end{tabular}

${ }^{2}$ If significant differences exist, letters indicate mean separation in columns by LSD, $P \leq 0.05$.

Ns, *,**Nonsignificant or significant at $P \leq 0.05$ or 0.01 , respectively.

Table 4. Effects of fertilizer treatments on 'Ozarka II' spinach, 1996-97, and on 'Alltop' turnip greens, 1997, Bixby, Okla. ${ }^{\text {' }}$

\begin{tabular}{|c|c|c|c|c|}
\hline \multirow{3}{*}{$\begin{array}{l}\text { Fertilizer } \\
\text { treatment }\end{array}$} & \multirow{3}{*}{$\begin{array}{c}\text { Stand at } \\
\text { harvest } \\
\text { (thousands/ha) }\end{array}$} & \multicolumn{3}{|c|}{ Harvested foliage } \\
\hline & & \multicolumn{2}{|c|}{ Fresh wt } & \multirow{2}{*}{$\begin{array}{c}\text { Dry wt } \\
(\%)\end{array}$} \\
\hline & & $\left(\mathrm{Mg} \cdot \mathrm{ha}^{-1}\right)$ & (g/plant) & \\
\hline \multicolumn{5}{|c|}{ Spinach, 1996-97 } \\
\hline Urea & $348 \mathrm{a}$ & 26.7 & $83 \mathrm{~b}$ & $13.4 \mathrm{ab}$ \\
\hline Litter $1 \times$ & 349 a & 27.4 & $85 \mathrm{~b}$ & $14.0 \mathrm{a}$ \\
\hline Litter $2 \times$ & $283 \mathrm{~b}$ & 28.9 & $110 \mathrm{a}$ & $12.5 \mathrm{~b}$ \\
\hline Significance & $*$ & NS & $* *$ & $*$ \\
\hline \multicolumn{5}{|c|}{ Turnip greens, 1997} \\
\hline Urea & 804 & $15.9 \mathrm{a}$ & 20 & $8.1 \mathrm{~b}$ \\
\hline Litter $1 \times$ & 707 & $12.5 \mathrm{~b}$ & 18 & $8.6 \mathrm{a}$ \\
\hline Litter $2 \times$ & 705 & $15.4 \mathrm{a}$ & 22 & $7.9 \mathrm{~b}$ \\
\hline Significance & NS & $* *$ & NS & * \\
\hline
\end{tabular}

${ }^{2}$ If significant differences exist, letters indicate mean separation in columns by LSD, $P \leq 0.05$. Main effects of cover crop and fertilizer treatment $\times$ cover crop interactions were nonsignificant for variables in this table.

Ns, *,** Nonsignificant or significant at $P \leq 0.05$ or 0.01 , respectively. 
tion was evident for turnip shoot $\mathrm{N}$ concentrations (Table 5). Nitrogen concentrations were affected by the cover crop treatment, but only in plants fertilized at the litter $1 \times$ rate. In the litter $1 \times$ plots, turnip greens following cowpeas had more $\mathrm{N}(6.1 \%)$ than those following fallow $(5.5 \%)$.

Fertilizer treatments affected concentrations of $\mathrm{K}, \mathrm{Ca}$, and $\mathrm{Mg}$ in turnip leaves, but did not affect concentrations of $\mathrm{P}, \mathrm{Mn}, \mathrm{Fe}$, or $\mathrm{Zn}$ (Table 5). The Kleaf concentration was smaller, and the $\mathrm{Ca}$ concentration was higher, in ureafertilized plants than in litter-fertilized plants. The $\mathrm{Mg}$ concentration was lower in litter $1 \times$ plants than in urea-fertilized plants, while $\mathrm{Mg}$ concentrations in litter $2 \times$ plants were not different from those of plants in the other fertilizer treatments (Table 5). Concentrations of $\mathrm{K}, \mathrm{Ca}$, and $\mathrm{Mg}$ did not differ between the litter $1 \times$ and $2 \times$ treatments, while yields were higher from litter $2 \times$ treatments than from litter $1 \times$ treatments (Table 4$)$. Therefore, differences in foliar $\mathrm{K}, \mathrm{Ca}$, and $\mathrm{Mg}$ concentrations probably were not major factors determining differences in turnip yield.

The concentration of Fe in the turnip greens was the only measured variable on any of the three vegetable crops for which the main effect of a cover crop treatment was significant. Turnip leaves contained $\mathrm{Fe}$ at $502 \mathrm{mg} \cdot \mathrm{kg}^{-1}$ following fallow vs. $401 \mathrm{mg} \cdot \mathrm{kg}^{-1}$ following cowpeas.

Cowpea cover crops. The fertilizer treatments did not affect foliar concentrations of $\mathrm{N}$, $\mathrm{P}, \mathrm{K}, \mathrm{Ca}, \mathrm{Mg}, \mathrm{Mn}, \mathrm{Fe}$, or $\mathrm{Zn}$ of cowpeas, nor shoot dry weight or seed fresh weight (Table 6). Years were not compared statistically, but the relatively low seed yield in 1996 probably resulted from an early harvest date; in retrospect, it would have been better to have waited one week. Earhart (1998) also reported that dry matter yields of cowpeas were not affected by increasing rates of poultry litter application.

Soils. In general, cover crop and fertilizer treatments had few significant main effects on plant nutrient concentrations in the soil (Tables 7, 8, and 9). Sampling time effects predominated, as expected, and there were some interactions of time with cover crop and fertilizer treatments.

$p H$. There was a main effect of fertilizer treatment on $\mathrm{pH}$ at the $0-15 \mathrm{~cm}$ soil sampling depth (Table 7). Soil $\mathrm{pH}$ values (6.3 in both cases) were higher from plots receiving litter at the $1 \times$ or $2 \times$ rates than from plots receiving urea (6.1). Litter $\mathrm{pH}$ (Table 1) was higher than the baseline soil $\mathrm{pH}$ (T1 in Table 7), so this result was expected. Gupta and Charles (1999) and Kingery et al. (1994) noted increased $\mathrm{pH}$ to a depth of $60 \mathrm{~cm}$ under soils with a longterm history of poultry litter application. Cover crop treatments affected $\mathrm{pH}$ at both soil sampling depths at $\mathrm{T} 3$ and $\mathrm{T} 5$, and at the $15-30 \mathrm{~cm}$ depth at T6, but not at other times (Tables 7 and 9). In all cases where a cover crop effect was evident, samples from plots following cowpeas showed higher $\mathrm{pH}$ values than samples from plots following fallow. Since soil $\mathrm{pH}$ effects were primarily at T3 and T5 (following cowpea incorporation), these effects may have been associated with decom-
Table 5. Foliar element concentrations of spinach (1996-97) and turnip greens (1997) in response to fertilizer treatments, Bixby, Okla. ${ }^{2}$

\begin{tabular}{|c|c|c|c|c|c|}
\hline \multirow{2}{*}{$\begin{array}{l}\text { Fertilizer } \\
\text { treatment }\end{array}$} & \multicolumn{5}{|c|}{ Foliar element concn (\%) } \\
\hline & $\mathrm{N}$ & $\mathrm{P}$ & $\mathrm{K}$ & $\mathrm{Ca}$ & $\mathrm{Mg}$ \\
\hline \multicolumn{6}{|c|}{ Spinach, 1996-97 } \\
\hline Urea & $4.6 \mathrm{ab}$ & 0.81 & 4.4 & 2.1 & 1.2 \\
\hline Litter $1 \times$ & $4.2 \mathrm{~b}$ & 0.80 & 4.6 & 2.2 & 1.2 \\
\hline Litter $2 \times$ & $4.7 \mathrm{a}$ & 0.86 & 4.7 & 2.4 & 1.3 \\
\hline Significance ${ }^{y}$ & $*$ & NS & NS & $I^{*}$ & NS \\
\hline \multicolumn{6}{|c|}{ Turnip greens, 1997} \\
\hline Urea & 6.3 & 0.53 & $4.5 \mathrm{~b}$ & $3.0 \mathrm{a}$ & $0.45 \mathrm{a}$ \\
\hline Litter $1 \times$ & 5.8 & 0.52 & $5.1 \mathrm{a}$ & 2.6 & $0.40 \mathrm{~b}$ \\
\hline Litter $2 \times$ & 5.9 & 0.55 & $5.4 \mathrm{a}$ & $2.6 \mathrm{~b}$ & $0.42 \mathrm{ab}$ \\
\hline Significance ${ }^{y}$ & $\mathrm{I}^{*}$ & NS & $* *$ & $*$ & $*$ \\
\hline \multicolumn{6}{|c|}{$\begin{array}{l}{ }^{2} \text { Within crops, if significant differences exist, letters indicate mean } \\
\text { separation in columns by LSD, } P \leq 0.05 \text {. Fertilizer treatment had no } \\
\text { significant }(P \leq 0.05) \text { effects on foliar concentrations of } \mathrm{Mn}, \mathrm{Fe} \text {, and } \mathrm{Zn} \\
\text { in either crop, so data are not presented. }\end{array}$} \\
\hline
\end{tabular}

position of residual cowpea tissues (primarily root systems)

Nitrogen. A cover crop $\times$ time interaction was evident for soil test $\mathrm{N}$ at both the $0-15 \mathrm{~cm}$ and $15-30 \mathrm{~cm}$ soil sampling depths (Table 7). Simple effects of cover crop treatment occurred at the two sampling times following cowpea incorporation (T3 and T5), but not at other times (Table 8). The cowpeas lowered soil test $\mathrm{N}$ concentrations at both soil sampling depths relative to the fallow plots. Some
$\mathrm{N}$ was removed with the cowpea pods and foliage (Table 6). Also, soil test $\mathrm{N}$ depression following cowpea incorporation was reported by Schroeder et al. (1998). A fertilizer treatment $\times$ time interaction also was detected for $\mathrm{N}$ at the $0-15 \mathrm{~cm}$ soil sampling depth (Table 7). Fertilizer treatment effects on soil test $\mathrm{N}$ were significant only at $\mathrm{T} 3$, at which time samples from litter $2 \times$ plots were higher in $\mathrm{N}$ than samples from plots treated with urea or litter at the $1 \times$ rate (Table 8 ).
Table 6. Foliar element concentrations and yields of cowpea cover crops in response to preceding fertilizer treatments, Bixby, Okla. ${ }^{2}$

\begin{tabular}{|c|c|c|c|c|c|c|c|}
\hline \multirow{2}{*}{$\begin{array}{l}\text { Fertilizer } \\
\text { treatment }\end{array}$} & \multicolumn{5}{|c|}{ Foliar element concn (\%) } & \multirow{2}{*}{$\begin{array}{c}\text { Shoot dry wt } \\
\left(\mathrm{Mg} \cdot \mathrm{ha}^{-1}\right)\end{array}$} & \multirow{2}{*}{$\begin{array}{c}\text { Seed fresh wt } \\
\left(\mathrm{Mg} \cdot \mathrm{ha}^{-1}\right)\end{array}$} \\
\hline & $\mathrm{N}$ & $\mathrm{P}$ & $\mathrm{K}$ & $\mathrm{Ca}$ & $\overline{\mathrm{Mg}}$ & & \\
\hline \multicolumn{8}{|c|}{1996} \\
\hline Urea & 3.2 & 0.44 & 2.1 & 2.1 & 0.67 & 4.2 & 1.0 \\
\hline Litter $1 \times$ & 2.8 & 0.45 & 2.2 & 2.3 & 0.63 & 3.8 & 1.3 \\
\hline Litter $2 \times$ & 3.4 & 0.48 & 2.4 & 2.2 & 0.63 & 4.2 & 1.0 \\
\hline \multicolumn{8}{|c|}{1997} \\
\hline Urea & 2.2 & 0.45 & 1.6 & 2.6 & 0.66 & 2.8 & 2.5 \\
\hline Litter $1 \times$ & 2.0 & 0.41 & 1.7 & 2.3 & 0.54 & 2.8 & 2.3 \\
\hline Litter $2 \times$ & 2.0 & 0.44 & 1.9 & 2.4 & 0.57 & 2.7 & 2.5 \\
\hline
\end{tabular}

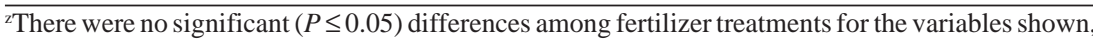
or for $\mathrm{Mn}, \mathrm{Fe}$, and $\mathrm{Zn}$. No fertilizer treatments were applied to the cowpeas. The fertilizer treatments were applied to broccoli (1995) and spinach (1996-97) crops preceding the 1996 and 1997 cowpea crops, respectively.

Table 7. Mean soil test values for $\mathrm{pH}$ and N, P, and K at six soil sampling times, Bixby, Okla.

\begin{tabular}{|c|c|c|c|c|c|c|c|c|}
\hline \multirow[b]{2}{*}{$\underline{\text { Variable }}$} & \multicolumn{6}{|c|}{ Sampling times $^{2}$} & \multicolumn{2}{|r|}{ Significance $^{y}$} \\
\hline & $\mathrm{T} 1$ & $\mathrm{~T} 2$ & T3 & $\mathrm{T} 4$ & T5 & T6 & Time & Other effects \\
\hline \multicolumn{9}{|c|}{$0-15 \mathrm{~cm}$ soil sampling depth } \\
\hline $\mathrm{pH}$ & 6.3 & 6.2 & 6.3 & 6.3 & 6.0 & 6.2 & $\mathrm{~L}^{* *}$ & $\mathrm{FT}^{* *}, \mathrm{CC} \times \mathrm{Time}^{* *}$ \\
\hline $\mathrm{N}\left(\mathrm{kg} \cdot \mathrm{ha}^{-1}\right)$ & 30 & 47 & 62 & 35 & 37 & 26 & $\mathrm{~L}^{* *}, \mathrm{Q}^{* *}$ & $\mathrm{CC} \times$ Time $^{* *}, \mathrm{FT} \times$ Time $^{*}$ \\
\hline $\mathrm{P}\left(\mathrm{kg} \cdot \mathrm{ha}^{-1}\right)$ & 275 & 280 & 250 & 239 & 276 & 283 & $\mathrm{Q}^{* *}$ & $\mathrm{FT}^{* *}, \mathrm{CC} \times \mathrm{Time}^{* *}, \mathrm{FT} \times \mathrm{Time}^{* *}$ \\
\hline $\mathrm{K}\left(\mathrm{kg} \cdot \mathrm{ha}^{-1}\right)$ & 419 & 395 & 414 & 364 & 412 & 411 & $\mathrm{Q}^{* *}$ & $\mathrm{CC} \times \mathrm{Time}^{* *}, \mathrm{FT} \times \mathrm{Time}^{*}$ \\
\hline \multicolumn{9}{|c|}{$15-30 \mathrm{~cm}$ soil sampling depth } \\
\hline $\mathrm{pH}$ & 6.1 & 6.0 & 6.1 & 6.3 & 5.8 & 6.1 & $\mathrm{~L}^{* *}, \mathrm{Q}^{* *}$ & $\mathrm{CC} \times \mathrm{Time}^{* *}$ \\
\hline $\mathrm{N}\left(\mathrm{kg} \cdot \mathrm{ha}^{-1}\right)$ & 39 & 37 & 47 & 8 & 40 & 31 & $\mathrm{~L}^{* *}, \mathrm{Q}^{* *}$ & $\mathrm{CC} \times \mathrm{Time}^{* *}$ \\
\hline $\mathrm{P}\left(\mathrm{kg} \cdot \mathrm{ha}^{-1}\right)$ & 255 & 234 & 211 & 186 & 230 & 219 & $\mathrm{~L}^{* *}, \mathrm{Q}^{* *}$ & $\mathrm{CC} \times$ Time $^{*}$ \\
\hline $\mathrm{K}\left(\mathrm{kg} \cdot \mathrm{ha}^{-1}\right)$ & 344 & 299 & 280 & 280 & 294 & 279 & $\mathrm{~L}^{* *}, \mathrm{Q}^{* *}$ & NS \\
\hline
\end{tabular}

zT1 = 25 July 1995 (baseline); T2 = 29 May 1996 (after fall broccoli and before cowpea planting); T3=3 Sept. 1996 (after cowpeas and before fall spinach planting); T4 = 14 May 1997 (after overwintered spinach and before cowpea planting); T5 = 19 Sept. 1997 (after cowpeas and before fall turnip greens planting); T6 = 13 May 1998 (termination, after fall turnip greens).

"Linear (L) and quadratic (Q) effects of time were tested. When "Other effects" (FT = Fertilizer treatments; $\mathrm{CC}=$ Cover crops) are significant, details are provided in subsequent tables.

ns, *,** Nonsignificant or significant at $P \leq 0.05$ or 0.01 , respectively. 
Phosphorus. Cowpea cover crops had no consistent effect on soil test $\mathrm{P}$ concentrations (Table 7). Cover crop $\times$ time interactions were evident for soil test $\mathrm{P}$ at both the $0-15$ $\mathrm{cm}$ and $15-30 \mathrm{~cm}$ soil sampling depths (Table 7). Cover crop treatment effects were detected for $\mathrm{P}$ at the $0-15 \mathrm{~cm}$ soil sampling depth only at T6 (Table 8), when plots with a history of cowpea cover crops had lower soil test $\mathrm{P}$ values than fallowed plots. However, this contrasts with the cover crop treatment effects detected for $\mathrm{P}$ at the $15-30 \mathrm{~cm}$ soil sampling depth. These simple effects, evident only at T3 and T4, showed higher soil test $\mathrm{P}$ values following cowpeas than following fallow (Table 8). These effects on soil test $\mathrm{P}$ at the $15-30 \mathrm{~cm}$ soil sampling depth apparently were associated with $\mathrm{P}$ mineralization following cowpea incorporation, since fertilizer treatments had no detectable effects on $\mathrm{P}$ concentrations at the $15-30 \mathrm{~cm}$ soil sampling depth (Table 7).

The cowpeas did not contain high concentrations of P (Table 6) and may not have accumulated enough removable biomass in the time frame available to have a major impact on soil test $P$ values. The cowpeas were managed not only as a cover crop but also as a cash crop, so that growers using this system would have some income before their primary fall vegetable crop. With the Oklahoma growing season, it was necessary to terminate the cowpea crops in August in order to allow time for field preparation before planting the fall vegetable crops.

There was a significant main effect of fertilizer treatment on soil test $\mathrm{P}$ at the $0-15$ cm soil sampling depth, but this was overridden by a fertilizer treatment $\times$ time interaction (Table 7). A breakdown of the interaction showed no effect of fertilizer treatment at T1 (the baseline sample, at which time no treatments had been applied) and at T3 (Table 8). At the other sampling times, plots fertilized with urea and with litter at the $1 \times$ rate were similar in soil test $P$ values at the $0-15$ cm soil sampling depth, but both had lower $P$ concentrations than plots fertilized with litter at the $2 \times$ rate (Table 8 ). Shepherd and Withers (1999) concluded that relatively large amounts of $\mathrm{P}$ would need to be applied to raise soil $\mathrm{P}$ status.

Potassium. Cover crop treatment effects on soil test $\mathrm{K}$ concentrations were detected only at the $0-15 \mathrm{~cm}$ soil sampling depth at T3 (Table 7), when higher values were found following cowpea incorporation than following fallow (Table 8). A fertilizer treatment $x$ time interaction also was evident for soil test $\mathrm{K}$ at the $0-15 \mathrm{~cm}$ soil sampling depth (Table 7).

Table 8. Details of cover crop $\mathrm{x}$ time and fertilizer treatment $\times$ time interactions affecting soil $\mathrm{pH}$ and soil test $\mathrm{N}, \mathrm{P}, \mathrm{K}$, and $\mathrm{Zn}$, Bixby, Okla. ${ }^{ }$

\begin{tabular}{|c|c|c|c|c|c|}
\hline \multirow[b]{2}{*}{ Sampling time } & \multicolumn{2}{|c|}{ Cover crop } & \multicolumn{3}{|c|}{ Fertilizer treatment } \\
\hline & Cowpea & Fallow & Urea & Litter $1 \times$ & Litter $2 \times$ \\
\hline \multicolumn{6}{|c|}{ pH, $0-15 \mathrm{~cm}$ soil sampling depth } \\
\hline T3 (3 Sept. 1996) & 6.4 & 6.2 & & & \\
\hline T5 (19 Sept. 1997) & 6.1 & 5.9 & & & \\
\hline \multicolumn{6}{|c|}{ pH, $15-30 \mathrm{~cm}$ soil sampling depth } \\
\hline T3 (3 Sept. 1996) & 6.2 & 6.0 & & & \\
\hline T5 (19 Sept. 1997) & 5.9 & 5.7 & & & \\
\hline T6 (13 May 1998) & 6.1 & 6.0 & & & \\
\hline \multicolumn{6}{|c|}{$N\left(\mathrm{~kg} \cdot \mathrm{ha^{-1 }}\right), 0-15 \mathrm{~cm}$ soil sampling depth } \\
\hline T3 (3 Sept. 1996) & 45 & 79 & $51 \mathrm{~b}$ & $62 \mathrm{~b}$ & $73 \mathrm{a}$ \\
\hline T5 (19 Sept. 1997) & 27 & 47 & & & \\
\hline \multicolumn{6}{|c|}{$N\left(\mathrm{~kg} \cdot \mathrm{ha^{-1 }}\right), 15-30 \mathrm{~cm}$ soil sampling depth } \\
\hline T3 (3 Sept. 1996) & 34 & 59 & & & \\
\hline T5 (19 Sept. 1997) & 8 & 72 & & & \\
\hline \multicolumn{6}{|c|}{$P\left(k g \cdot h a^{-1}\right), 0-15 \mathrm{~cm}$ soil sampling depth } \\
\hline T2 (29 May 1996) & & & $271 \mathrm{~b}$ & $271 \mathrm{~b}$ & 298 a \\
\hline T4 (14 May 1997) & & & $223 \mathrm{~b}$ & $233 \mathrm{~b}$ & $260 \mathrm{a}$ \\
\hline T5 (19 Sept. 1997) & & & $264 \mathrm{~b}$ & $270 \mathrm{~b}$ & $295 \mathrm{a}$ \\
\hline T6 (13 May 1998) & 272 & 293 & $242 b$ & $265 \mathrm{~b}$ & $341 \mathrm{a}$ \\
\hline \multicolumn{6}{|c|}{$P\left(k g \cdot h a^{-1}\right), 15-30 \mathrm{~cm}$ soil sampling depth } \\
\hline T3 (3 Sept. 1996) & 220 & 201 & & & \\
\hline T4 (14 May 1997) & 195 & 178 & & & \\
\hline \multicolumn{6}{|c|}{$K\left(\mathrm{~kg} \cdot \mathrm{ha} \mathrm{a}^{-1}\right), 0-15 \mathrm{~cm}$ soil sampling depth } \\
\hline T3 (3 Sept. 1996) & 445 & 384 & $387 \mathrm{~b}$ & $409 \mathrm{ab}$ & $446 \mathrm{a}$ \\
\hline T6 (13 May 1998) & & & $379 b$ & $410 \mathrm{ab}$ & $445 \mathrm{a}$ \\
\hline \multicolumn{6}{|c|}{ Zn $\left(m g \cdot h a^{-1}\right), 0-15 \mathrm{~cm}$ soil sampling depth } \\
\hline T3 (3 Sept. 1996) & & & $2.1 \mathrm{c}$ & $2.2 \mathrm{~b}$ & $2.4 a$ \\
\hline T5 (19 Sept. 1997) & & & $1.7 \mathrm{~b}$ & $1.7 \mathrm{~b}$ & $1.9 a$ \\
\hline \multicolumn{6}{|c|}{ Zn $\left(m g \cdot h a^{-1}\right), 15-30 \mathrm{~cm}$ soil sampling depth } \\
\hline T3 (3 Sept. 1996) & 1.8 & 1.4 & & & \\
\hline
\end{tabular}

${ }^{2}$ Data are shown only for times when a significant cover crop or fertilizer treatment effect was found. For each variable, within sampling times, cover crop means shown differ by least squares, $P \leq 0.05$, and letters under fertilizer treatments indicate mean separation in rows by least squares, $P \leq 0.05$. No effects of cover crops or fertilizer treatments were found at T1 (25 July 1995), since no treatments had been applied. No effects of cover crops were found at T2 (29 May 1996), since cover crops had not yet been grown on the land.

There were no differences in K concentrations between plots treated with litter at the $1 \times$ and $2 \times$ rates (Table 8 ). However, litter $2 \times$ plots had more soil test $\mathrm{K}$ than urea plots at the $0-15 \mathrm{~cm}$ soil sampling depth at T3 and T6. Earhart (1995) reported increased $\mathrm{K}$ accumulation in the surface $30 \mathrm{~cm}$ of soil following poultry litter applications at double the recommended rate.

Cover crop and fertilizer treatments had no detectable effects on soil test $\mathrm{K}$ at the 15-30 $\mathrm{cm}$ soil sampling depth (Table 7). Only the main effect of time was significant for this variable, and the response was a quadratic decrease over time (Table 7).

Secondary nutrients and micronutrients. Cover crop and fertilizer treatments had no detectable effects on concentrations of $\mathrm{Ca}$, $\mathrm{Mg}$, or Fe at either soil sampling depth, or on $\mathrm{B}$ at the $0-15 \mathrm{~cm}$ soil sampling depth (Table 9). A three-way interaction was found for soil test B at the $15-30 \mathrm{~cm}$ soil sampling depth (Table 9). Simple effects of fertilizer treatments were found only in fallow plots at T3 and in plots with incorporated cowpeas at T5. A simple effect of cover crop treatments was found only in litter $2 \times$ plots at T5. Effects of either factor (cover crop or fertilizer treatment) were not always consistent given the other factor (data not presented). Overall, treatments appeared to have minimal effects on soil test $\mathrm{B}$ concentrations.

A cover crop $\times$ time interaction was evident for soil test $\mathrm{Zn}$ at the $0-15 \mathrm{~cm}$ soil sampling depth (Table 9). However, when the interaction was partitioned, means for cowpea plots and for fallow plots were not significantly different at any one sampling time (data not presented). The overall interaction probably resulted from order of magnitude effects when comparing differences between cowpea and fallow means at each given time, and because the cowpea mean was not consistently numerically higher than the fallow mean (fallow was higher at T5). A cover crop $\times$ time interaction also was evident for soil test $\mathrm{Zn}$ at the $15-30 \mathrm{~cm}$ soil sampling depth (Table 9). The main effect of cover crop suggested that $\mathrm{Zn}$ concentrations were higher with cowpea cover crops than with fallow, but since the interaction showed this difference was significant only at T3 (Table 8), this effect likely is of little practical significance.

There was a significant main effect of fertilizer treatment on soil test $\mathrm{Zn}$ at the $0-15$ $\mathrm{cm}$ soil sampling depth, but this was overridden by a fertilizer treatment $\times$ time interaction (Table 9). Simple effects of fertilizer treatment occurred at $\mathrm{T} 3$ and at $\mathrm{T} 5$, but not at T1 (Table 8 ). The litter $2 \times$ treatment resulted in the highest soil test $\mathrm{Zn}$ concentrations at the $0-15 \mathrm{~cm}$ soil sampling depth at both T3 and T5, while the litter $1 \times$ treatment increased $\mathrm{Zn}$ concentrations relative to urea only at T3. Our poultry litter lots were not analyzed for $\mathrm{Zn}$. Others have reported increases (Kingery et al., 1994; Shuman and McCracken, 1999) or no changes (Gupta and Charles, 1999) in extractable soil Zn over time following poultry litter applications. 
Table 9. Mean soil test values for $\mathrm{Ca}, \mathrm{Mg}, \mathrm{Fe}, \mathrm{B}$, and $\mathrm{Zn}$ at three soil sampling times, Bixby, Okla.

\begin{tabular}{|c|c|c|c|c|c|}
\hline \multirow[b]{2}{*}{ Variable } & \multicolumn{3}{|c|}{ Sampling times ${ }^{\mathrm{z}}$} & \multicolumn{2}{|r|}{ Significance $^{\mathrm{y}}$} \\
\hline & $\mathrm{T} 1$ & $\mathrm{~T} 3$ & T5 & Time & Other effects \\
\hline \multicolumn{6}{|c|}{$0-15 \mathrm{~cm}$ soil sampling depth } \\
\hline $\mathrm{Ca}\left(\mathrm{kg} \cdot \mathrm{ha}^{-1}\right)$ & 2889 & 2691 & 2725 & $\mathrm{~L}^{* *}, \mathrm{Q}^{* *}$ & NS \\
\hline $\operatorname{Mg}\left(\mathrm{kg} \cdot \mathrm{ha}^{-1}\right)$ & 424 & 423 & 430 & NS & NS \\
\hline $\mathrm{Fe}\left(\mathrm{mg} \cdot \mathrm{kg}^{-1}\right)$ & 42 & 61 & 31 & $\mathrm{~L}^{* *}, \mathrm{Q}^{* *}$ & NS \\
\hline $\mathrm{B}\left(\mathrm{mg} \cdot \mathrm{kg}^{-1}\right)$ & 0.30 & 0.42 & 0.40 & $\mathrm{~L}^{* *}, \mathrm{Q}^{* *}$ & NS \\
\hline $\mathrm{Zn}\left(\mathrm{mg} \cdot \mathrm{kg}^{-1}\right)$ & 1.5 & 2.3 & 1.7 & $\mathrm{~L}^{* *}, \mathrm{Q}^{* * *}$ & $\mathrm{FT}^{*}, \mathrm{CC} \times \mathrm{Time}^{* *}, \mathrm{FT} \times$ Time \\
\hline \multicolumn{6}{|c|}{$15-30 \mathrm{~cm}$ soil sampling depth } \\
\hline $\mathrm{Ca}\left(\mathrm{kg} \cdot \mathrm{ha}^{-1}\right)$ & 2927 & 2722 & 2837 & $\mathrm{~L}^{* *}, \mathrm{Q}^{* *}$ & NS \\
\hline $\operatorname{Mg}\left(\mathrm{kg} \cdot \mathrm{ha}^{-1}\right)$ & 415 & 422 & 434 & $\mathrm{~L}^{* * *}$ & NS \\
\hline $\mathrm{Fe}\left(\mathrm{mg} \cdot \mathrm{kg}^{-1}\right)$ & 45 & 64 & 32 & $\mathrm{~L}^{* *}, \mathrm{Q}^{* *}$ & NS \\
\hline $\mathrm{B}\left(\mathrm{mg} \cdot \mathrm{kg}^{-1}\right)$ & 0.28 & 0.38 & 0.36 & $\mathrm{~L}^{* *}, \mathrm{Q}^{* *}$ & $\mathrm{CC} \times \mathrm{FT} \times \mathrm{Time}^{*}$ \\
\hline $\mathrm{Zn}\left(\mathrm{mg} \cdot \mathrm{kg}^{-1}\right)$ & 1.3 & 1.6 & 1.2 & $\mathrm{~L}^{* *}, \mathrm{Q}^{* *}$ & $\mathrm{CC}^{* *}, \mathrm{CC} \times \mathrm{Time}^{* *}$ \\
\hline
\end{tabular}

${ }^{2}$ T1 = 25 July 1995; T3 = 3 Sept. 1996; T5 = 19 Sept. 1997.

'Linear (L) and quadratic (Q) effects of time were tested. When "Other effects" (FT = fertilizer treatments; $\mathrm{CC}=$ cover crops) are significant, details are provided in other tables or the text.

ss, ${ }^{*}$, Nonsignificant or significant at $P \leq 0.05$ or 0.01 , respectively.

\section{Conclusions}

Removing cowpea pods and foliage and incorporating residues of cowpea cover crops lowered soil test $\mathrm{N}$, which could potentially reduce leaching losses through the soil profile. However, this also would reduce $\mathrm{N}$ available to the succeeding vegetable crop (Schroeder et al., 1998). The cowpeas had no consistent effect on soil test $\mathrm{P}$ concentrations. Therefore, under our conditions, there would be little justification for growing a cowpea cover crop as a means of managing soil $\mathrm{P}$ accumulation from poultry litter applications.

Three cool-season vegetable crops were successfully grown with poultry litter, but the litter $1 \times$ rate usually was insufficient to meet crop needs. Since the litter $2 \times$ rate resulted in demonstrable increases in soil test $\mathrm{P}$ at the $0-15 \mathrm{~cm}$ soil sampling depth, increasing the amount of litter applied preplant to the vegetable crops just to meet their $\mathrm{N}$ requirements would not be recommended. A better approach might be to supplement a litter $1 \times$ application with a readily-available $\mathrm{N}$ source. Litter at the $1 \times$ rate was not shown to raise soil test $\mathrm{P}$ values. Research should continue on ways to efficiently utilize poultry litter in horticultural production systems.

\section{Literature Cited}

Brown, J.E., J.M. Dangler, C.H. Gilliam, D.W.Porch, and R.L. Shumack. 1994. Comparison of broiler litter and inorganic nitrogen, phosphorus, and potassium for double-cropped sweet corn and broccoli. J. Plant Nutr. 17:859-867.

Daniel, H.A. 1934. The calcium, phosphorus, and nitrogen content of grasses and legumes and the relation of these elements in the plant. J. Amer. Soc. Agron. 26:496-503.

Earhart, D.R. 1995. Developing environmentally sound poultry litter management practices for sustainable cropping systems. Final report, project LS92-48. Southern Reg. Sustainable Agr. Res. and Educ. Program.

Earhart, D.R. 1998. Managing soil phosphorus accumulation from poultry litter application through vegetable/legume rotations. Final report, project LS95-69. Southern Reg. Sustainable Agr. Res. and Educ. Program.

Edwards, D.R. and T.C. Daniel. 1992. Environmental impacts of on-farm poultry waste disposal: A review. Bioresource Technol. 41:9-33.

Edwards, D.R. and T.C. Daniel. 1993. Effects of poultry litter application rate and rainfall intensity on quality of runoff from fescuegrass plots. J. Environ. Qual. 22:361-365.

Griffith, W.K. 1974. Satisfying the nutritional requirements of established legumes, p. 147-169. In: D.A. Mays (ed.). Forage fertilization. Amer. Soc. Agron., Crop Sci. Soc. of Amer., and Soil Sci. Soc. of Amer., Madison, Wis.

Guertal, E.A., B.K. Behe, and J.M. Kemble. 1997. Composted poultry litter as potting media does not affect transplant nitrogen content or final crop yield. HortTechnology 7:142-145.

Gupta, G. and S. Charles. 1999. Trace elements in soils fertilized with poultry litter. Poultry Sci. 78:1695-1698.

Hargrove, W.L. 1986. Winter legumes as a nitrogen source for no till grain sorghum. Agron. J. 78:7074.

Kingery, W.L., C.W. Wood, D.P. Delaney, J.C. Williams, and G.L. Mullins. 1994. Impact of long- term land application of broiler litter on environmentally related soil properties. J. Environ. Qual. 23:139-147.

Lal, R., E. Regnier, D.J. Eckert, W.M. Edwards, and R. Hammond. 1991. Expectations of cover crops for sustainable agriculture, p. 1-11. In: W.L. Hargrove (ed.). Cover crops for clean water. Soil and Water Conservation Soc., Ankeny, Iowa.

Lu, N.P. and J.H. Edwards. 1994. Poultry litter quantity influences collard growth in pots and affects cabbage growth and nutrient uptake. HortScience 29:1143-1148.

Maynard, A.A. 1994. Sustained vegetable production for three years using composted animal manures. Compost Sci. and Utilization 2(1):88-96.

National Agricultural Statistics Service. 1998. Poultry production and value. Bul. Pou 3-1(98). U.S. Dept. Agr., Washington, D.C.

Nichols, D.J., T.C. Daniel, and D.R. Edwards. 1994. Nutrient runoff from pasture after incorporation of poultry litter or inorganic fertilizer. Soil Sci. Soc. Amer. J. 58:1224-1228.

Nicholson, F.A., B.J. Chambers, K.A. Smith, and R. Harrison. 1999. Spring applied organic manures as a source of nitrogen for cereal crops: Experiments using field scale equipment. J. Agr. Sci. (Cambridge) 133:353-363.

SAS Institute. 1999. SAS/STAT User's Guide, version 8. SAS Inst., Cary, N.C.

Schroeder, J.L., B.A. Kahn, and J.Q. Lynd. 1998. Utilization of cowpea crop residues to reduce fertilizer nitrogen inputs with fall broccoli. Crop Sci. 38:741-749.

Sharpley, A.N., S.J. Smith, and W.R. Bain. 1993. Nitrogen and phosphorus fate from long-term poultry litter applications to Oklahoma soils. Soil Sci. Soc. Amer. J. 57:1131-1137.

Shepherd, M.A. and P.J. Withers. 1999. Applications of poultry litter and triple superphosphate fertilizer to a sandy soil: Effects on soil phosphorus status and profile distribution. Nutrient Cycling in Agroecosystems 54(3):233-242.

Shuman, L.M. and D.V. McCracken. 1999. Tillage, lime, and poultry litter effects on soil zinc, manganese, and copper. Commun. Soil Sci. Plant Anal. 30:1267-1277.

Sims, J.T. and D.C. Wolf. 1994. Poultry waste management: Agricultural and environmental issues. Adv. in Agron. 52:1-83.

Ware, L.M. and W.A. Johnson. 1968. Poultry manure for vegetable crops-Effects and value. Agr. Expt. Sta., Auburn Univ., Auburn, Ala. Res. Bul. 386.

Wilson, G.F., R. Lal, and B.N. Okigbo. 1982. Effects of cover crops on soil structure and on yield of subsequent arable crops grown under strip tillage on an eroded Alfisol. Soil Tillage Res. 2:233250 .

Zhang, H., M. Kress, and G. Johnson. 1998. Procedures used by OSU soil, water, and forage analytical laboratory. Okla. Coop. Ext. Serv., Stillwater, Okla. Ext. Facts F-2901. 